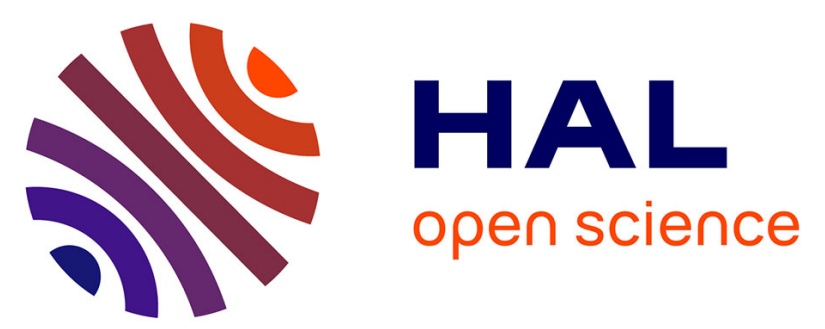

\title{
Comparative temperature tolerance in stingless bee species from tropical highlands and lowlands of Mexico and implications for their conservation (Hymenoptera: Apidae: Meliponini)
}

José Macías-Macías, José Quezada-Euán, Francisca Contreras-Escareño, José Tapia-Gonzalez, Humberto Moo-Valle, Ricardo Ayala

\section{To cite this version:}

José Macías-Macías, José Quezada-Euán, Francisca Contreras-Escareño, José Tapia-Gonzalez, Humberto Moo-Valle, et al.. Comparative temperature tolerance in stingless bee species from tropical highlands and lowlands of Mexico and implications for their conservation (Hymenoptera: Apidae: Meliponini). Apidologie, 2011, 42 (6), pp.679-689. 10.1007/s13592-011-0074-0 . hal-01003611

\section{HAL Id: hal-01003611 \\ https://hal.science/hal-01003611}

Submitted on 1 Jan 2011

HAL is a multi-disciplinary open access archive for the deposit and dissemination of scientific research documents, whether they are published or not. The documents may come from teaching and research institutions in France or abroad, or from public or private research centers.
L'archive ouverte pluridisciplinaire HAL, est destinée au dépôt et à la diffusion de documents scientifiques de niveau recherche, publiés ou non, émanant des établissements d'enseignement et de recherche français ou étrangers, des laboratoires publics ou privés. 


\title{
Comparative temperature tolerance in stingless bee species from tropical highlands and lowlands of Mexico and implications for their conservation (Hymenoptera: Apidae: Meliponini)
}

\author{
José Octavio Macías-Macías ${ }^{1}$, José Javier G. QueZada-EuÁN ${ }^{2}$, \\ Francisca Contreras-Escareño ${ }^{1}$, José Maria TAPIA-GONZALEZ ${ }^{3}$, \\ Humberto Moo-VALLE ${ }^{2}$, Ricardo AyALA ${ }^{4}$

\footnotetext{
${ }^{1}$ Laboratorio de Abejas, Departamento de Producción Agrícola, Centro Universitario de la Costa Sur, Universidad de Guadalajara, Independencia Nacional 151, Autlán de Navarro, Jalisco, Mexico

${ }^{2}$ Departamento de Apicultura, Facultad de Medicina Veterinaria y Zootecnia, Universidad Autónoma de Yucatán, Apartado postal 4-116, CP 97100, Mérida, Yucatán, Mexico

${ }^{3}$ Departamento de Producción Animal, Centro Universitario del Sur, Universidad de Guadalajara, Zapotlán el Grande, Jalisco, Mexico

${ }^{4}$ Estación de Biología Chamela, Instituto de Biología, Universidad Nacional Autónoma de México, Apartado Postal 21, San Patricio, Jalisco 48980, Mexico
}

Received 18 August 2010 - Revised 1 February 2011 - Accepted 2 February 2011

\begin{abstract}
The objective of this study was to evaluate the temperature sensitivity of three stingless bee species, one from the tropical highland transition Neartic-Neotropical region (Melipona colimana) and two from the tropical lowland regions (Melipona beecheii and Scaptotrigona hellwegeri) of Mexico. The changes in thoracic temperature, behavior, and mortality rate of workers and pupae of the three species submitted to control high and low temperatures were assessed. Workers of highland M. colimana regurgitated water and fanned their wings when submitted to high temperatures, a behavior reported here for the first time in a stingless bee. M. colimana consumed syrup and increased its thoracic temperature in response to cold environment. Workers and pupae of $M$. colimana experienced lower mortality rates than $M$. beecheii and $S$. hellwegeri. The results of this study showed the tolerance of $M$. colimana to a wider temperature range, possibly as a response to extreme conditions in its native environment. The implications of thermal susceptibility differences for the conservation of highland and lowland stingless bees are discussed.
\end{abstract}

Melipona / Scaptotrigona / Apidae / temperature tolerance / behavior / temperate forest / Mexico

\section{INTRODUCTION}

Critical temperatures are defined as the limits of an organism's performance and may reflect adaptation of ectotherms to their climate (Deutsch et al. 2008). Thermal tolerance curves

Corresponding author: J.O. Macías-Macías, joseoc@cucsur.udg.mx

Manuscript editor: Stan Schneider also provide a physiological framework that may help to predict the effect of climatic change on different taxa (Huey and Stevenson 1979; Frazier et al. 2006). In spite of the importance of temperature tolerance data in insects, studies on temperature tolerance in bees other than the honeybees are lacking. In stingless bees, there is a lack of information on thermal performance of different species, which is urgently needed in order to evaluate the effects of habitat deterio- 
ration and climatic change on these key pollinators of the tropical and subtropical areas of the world. In eusocial bees (Apini and Meliponini), colonies are perennial and the production of individuals is continuous over long periods of time. Such features are linked to the ability of colonies to control nest temperatures within ranges that are optimal for the development of the immature brood (Tautz et al. 2003; Jones et al. 2005; Mc Mullan and Brown 2005). The adult workers of eusocial bees exhibit an array of physiological and behavioral responses to extreme variations in the environment to maintain internal nest temperatures (Heinrich 1993; Jones and Oldroyd 2007). The mechanisms that social insects have evolved to regulate nest temperature fall into two categories: active and passive. Passive mechanisms include nest site selection, nest structures, and simple behaviors such as brood translocation. On the other hand, active mechanisms involve behaviors where individuals modify nest temperature by physical activity like wing fanning or evaporative cooling (Jones et al. 2005; Jones and Oldroyd 2007). In stingless bees, the role of maintaining nest homeostasis is not clear (Zucchi and Sakagami 1972; Fletcher and Crewe 1981; Roubik 1983). For instance, species like Nannotrigona perilampoides collect water at high environmental temperatures (Cauich et al. 2004), but it is unknown if water is used to actively cool down their nest by wing fanning and evaporation (Roubik 2006). Most species of stingless bees are geographically restricted to low tropical and subtropical regions which could be a result of their limited ability to warm up their nests at low environmental temperatures. However, few species also dwell at tropical highlands and may show tolerance to cold by means of active mechanism, but this has not been evaluated (Sakagami 1982; Wille 1983; Ortiz-Mora et al. 1995; Nogueira-Neto 1997). Accordingly, all studies of temperature control in stingless bee colonies have been conducted on species that inhabit Neotropical environments (Zucchi and Sakagami 1972; Fletcher and Crewe 1981; Roubik and Peralta 1983) and have not compared the individual response of workers and immature stages of species from highland and lowland tropics. Thus, stingless bee species, inhabiting contrasting climates, represent potential models on which to evaluate the individual physiology and behavior of temperature control that may lead to adaptation to these environments. Tolerance to extreme cold and heat in brood and adult workers of highland Melipona colimana and lowland Melipona beecheii and Scaptotrigona hellwegeri was studied in order to compare the behavioral and physiological responses to temperature fluctuation resulting from adaptation to their contrasting environments. The study of these species may help to determine the ability to maintain nest homeostasis that may exist in stingless bees given the diverse range of habitats and nesting sites across the tropics.

\section{MATERIALS AND METHODS}

\subsection{Study site and species description}

The study was conducted at the Centro Universitario del Sur (CUSUR) of the Universidad de Guadalajara in Ciudad Guzman, Jalisco, Mexico, localized at a latitude of $19^{\circ} 42^{\prime} 10^{\prime \prime}$ and longitude of $103^{\circ} 27^{\prime} 45^{\prime \prime}$ with an altitude of $1,507 \mathrm{~m}$ above sea level (masl). Three stingless bee species, one from the tropical highlands (M. colimana) and two from the lowland tropics (M. beecheii and S. hellwegeri), were used. M. colimana Ayala 1999 has a marked geographic endemism to the highland pine-oak forests of western Mexico (south of Jalisco state). This species has a black integument with yellow marks, orange pubescence, with a body length of $9.5 \mathrm{~mm}$, and weight of $0.067 \mathrm{~g}$. It has only been reported in tropical highlands from 1,500 to 1,900 masl (Ayala 1999). The temperature in the western pine forest in Mexico is, on average, $23.1^{\circ} \mathrm{C}$ during the summer and $18.6^{\circ} \mathrm{C}$ in the winter, but temperatures of $7^{\circ} \mathrm{C}$ can be common, and in this area, there are reports of temperatures lower than $10^{\circ} \mathrm{C}$ for up to 40 days at a time (CONAGUA 2007b). The other two species under study, M. beecheii and S. hellwegeri, are only found in low subtropical and tropical rain forests with sea level records at a maximum altitude 
of 1,100 masl, with a temperature average of $28.7^{\circ} \mathrm{C}$ and 900 to $1,100 \mathrm{~mm}$ of rain (Ayala 1999; CONAGUA 2007a). M. beecheii is a species with a body length between 9.7 and $10.7 \mathrm{~mm}$, with a body weight of $0.057 \mathrm{~g}$. It presents an almost total black integument with brownish-gray and black drawings on the legs, whitish pubescence at the sides of the mesosome, and ochre or orange on the rest of the body. S. hellwegeri has a body length of 4.7 to $5.1 \mathrm{~mm}$ with an orange and black integument (Ayala 1999), with a weight of $0.013 \mathrm{~g}$. It was decided to use $S$. hellwegeri as a point of comparison with another tropical climate stingless bee genus, since some internal environmental control behaviors have been previously reported in other Scaptotrigona species (Scaptotrigona postica) (Engels et al. 1995). The geographic distribution of these species encompasses the Gulf and Pacific coasts of Mexico (Ayala 1999), thus with a distribution geographically close to that of M. colimana (Figure 1). Specimens of five colonies were evaluated for each of the three bee species. All the colonies were moved to the CUSUR campus. Two experiments were conducted under controlled low and high temperatures: the first to evaluate the individual response (measured as changes in the thoracic temperature) and the behavior of groups of worker bees (measured as syrup and water consumption and wing fanning) and a second to determine the tolerance (measured by survival rate) of workers and brood pupae.

\subsection{Thoracic temperature and behavior of adult workers at high and low temperatures}

First, the change in the thoracic temperature of bees under controlled low and high temperatures was evaluated. From each colony, 100 workers were taken from the brood area and were placed in wooden boxes $(12.5 \times 7 \times 5 \mathrm{~cm})$ with two plastic feeders, one containing sugar syrup 2:1 (sugar/water) and another one containing only water. The groups of bees were kept for five hours at $7^{\circ} \mathrm{C}$, which is the minimum temperature that has been recorded at the locality of origin of $M$. colimana. Temperature records were taken on the thorax of 40 individuals every hour using an infrared thermometer (Infrapro Oakton Mod. 36629-20). Syrup and water consumption were recorded every hour in each group. The experiment was repeated after 5 days with different samples of bees from different colonies of each species. To evaluate the behavior of bees at high temperatures, a similar procedure was

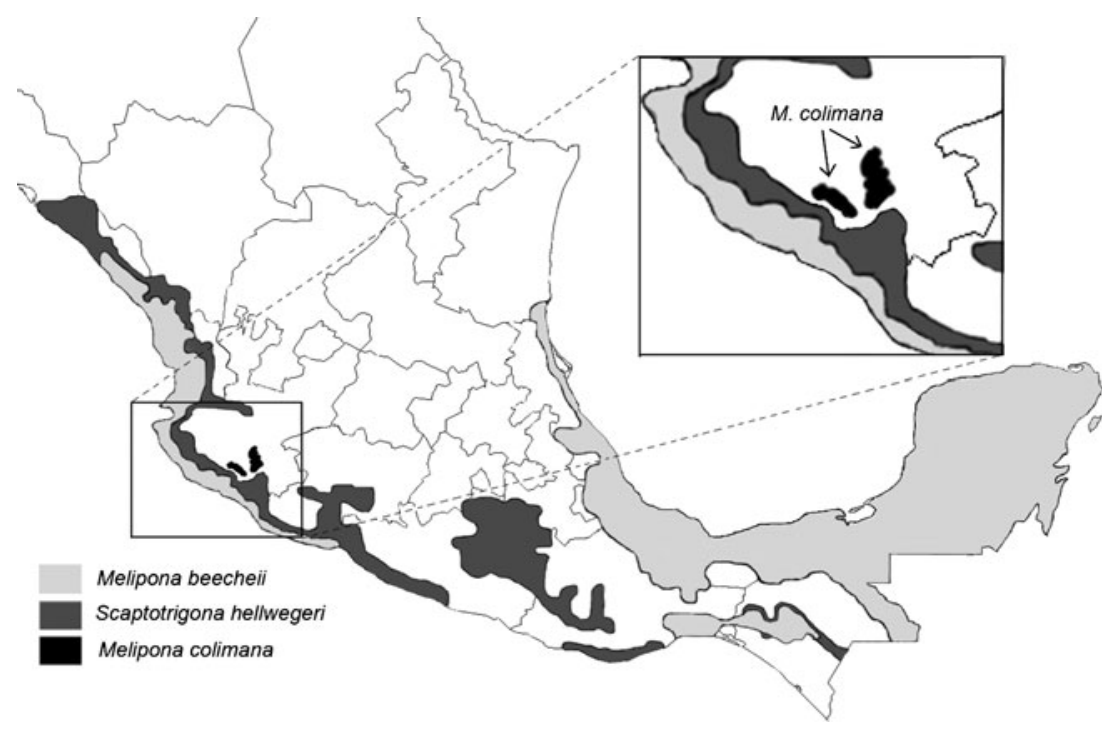

Figure 1. Distribution of M. colimana, M. beecheii, and S. hellwegeri in Mexico (based on data from Ayala 1999). 
followed, but this time, the bees were kept at $40^{\circ} \mathrm{C}$ in an incubator (Ter-Lab NB-100). For the experiment at high temperatures, the change in thoracic temperature, the number of bees fanning, and the volume of water and syrup consumed were recorded every hour. A control group of 100 bees of each species was kept at room temperature $\left(25.14 \pm 1.43^{\circ} \mathrm{C}\right)$, and the same variables were recorded as in the experimental groups. An additional experiment was conducted on the three species, but the groups of bees were kept at $7^{\circ} \mathrm{C}$ for $24 \mathrm{~h}$. The thoracic temperature was registered once at the end of this period of time when the bees were under cold-induced lethargy and again when they recovered mobility. Additionally, the number of dead bees and bees which regained mobility and the time it took for their full recovery were recorded. The results of thoracic temperatures between the three species were compared with ANOVA (Zar 1999), as were thoracic temperatures of cold-induced lethargic bees, number of dead bees, number of bees that recovered movement, and the time elapsed between cold-induced lethargy and recovering in the latter. The consumption of water and sugar syrup was correlated with thoracic temperature and fanning bees with a Pearson correlation. The software Statgraphics Plus ${ }^{\circledR}$ (Statistical Graphics Corp. 1999) was used for statistical analyses.

\subsection{Temperature tolerance of adults and pupae}

In this part of the study, adult workers and pupae of M. colimana, M. beecheii, and S. hellwegeri from five different colonies were submitted to a range of extreme temperatures during $24 \mathrm{~h}$ (Mardan and Kevan 2002; Dias and Aparecido 2004). Ten workers from the brood nest were taken to evaluate adult individuals by putting them in observation wooden boxes, with the same dimensions as the experiments in 2.2 and with the same type of feeders. Brood comb sections, which contained an amount of $\sim 80$ pupae were used in the experiments (Mardan and Kevan 2002). All pupae were at the same stage of growth, with pink eyes ( $M$. colimana and $M$. beecheii pupae between 40 and 45 days of age and $S$. hellwegeri between 30 and 35 days). Each group of 10 bees and the combs were submitted to different low temperatures $\left(-10^{\circ} \mathrm{C},-5^{\circ} \mathrm{C}\right.$, $-2^{\circ} \mathrm{C}, 2^{\circ} \mathrm{C}$, and $\left.5^{\circ} \mathrm{C}\right)$ and high temperatures $\left(30^{\circ} \mathrm{C}, 33^{\circ}\right.$ $\mathrm{C}, 36^{\circ} \mathrm{C}, 38^{\circ} \mathrm{C}$, and $40^{\circ} \mathrm{C}$ ) for $24 \mathrm{~h}$. Five replicates were made for each of the ten temperatures, one per colony. Five control groups with adult bees and brood were kept at room temperature $\left(25.14^{\circ} \mathrm{C} \pm 1.43^{\circ} \mathrm{C}\right)$ during the experiments. The mortality rate was measured after $24 \mathrm{~h}$. All individuals inactive $1 \mathrm{~h}$ after ending the experiments were considered dead. The consumption of water and syrup was recorded at the end of the experiment. Estimation of the lethal temperatures to reach $50 \%$ and $100 \%$ mortality (LT50 and LT100) was made by means of the analysis of PROBIT using the statistical package for the social sciences (SPSS 2006). A Pearson's correlation analysis was performed between the mortality percentage and temperature for pupae and adults. Additionally, the relationship between water and syrup consumption at different temperatures was also analyzed for each species using a Pearson's correlation.

\section{RESULTS}

\subsection{Thoracic temperature and behavior of adult workers at high and low temperatures}

Important differences in thoracic temperature among the three bee species were observed when they were subjected to $7^{\circ} \mathrm{C}(F=165.35$; $\mathrm{DF}=2,72 ; P<0.01)$, room temperature $(F=$ 112.08; $\mathrm{DF}=2,72 ; P<0.01)$, and extreme heat of $40^{\circ} \mathrm{C}(F=106.51 ; \mathrm{DF}=2,72 ; P<0.01) . M$. colimana workers had higher values under the three temperature treatments (Figure 2).

When the three species were exposed to cold conditions, only the workers of $M$. colimana consumed syrup, with an average of $2.9 \pm$ $0.25 \mathrm{ml}$ of syrup consumed at the end of $5 \mathrm{~h}$. Syrup consumption increased with thoracic temperature, yielding a positive correlation of $0.677(F=19.50, \mathrm{DF}=23, P<0.01)$ (Figure 3).

In groups of bees at room temperature $(25.14 \pm$ $1.43^{\circ} \mathrm{C}$ ), consumption of syrup, water, or fanning was not observed for any of the three species. On the other hand, in bees subjected to $40^{\circ} \mathrm{C}$, water consumption occurred in all three species; moreover, water consumption $(F=66.96 ; \mathrm{DF}=2,72 ; P$ $<0.01$ ) was significantly higher in $M$. colimana compared with the other two species. On average, M. colimana consumed $4.20 \pm 2.13 \mathrm{ml}$

\section{Springer SDIB INRA}




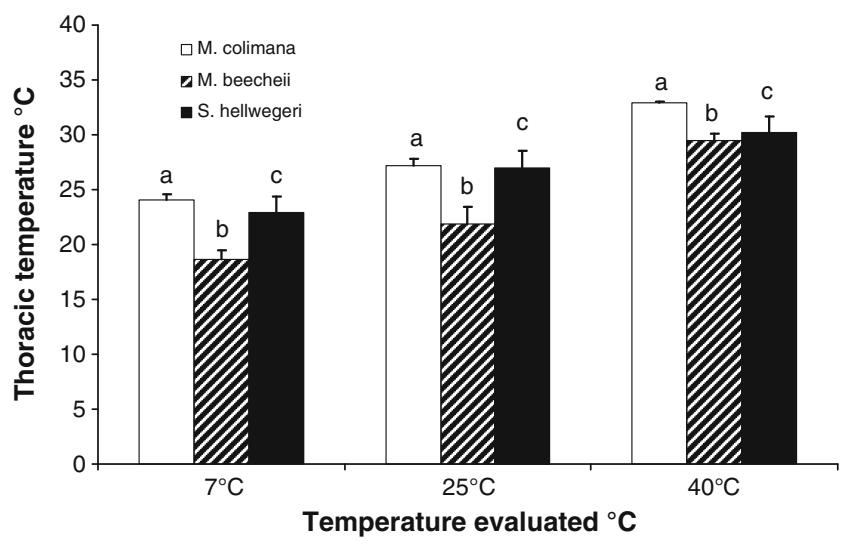

Figure 2. Thoracic temperatures of $M$. colimana, M. beecheii, and $S$. hellwegeri subjected to cold temperatures $\left(7^{\circ} \mathrm{C}\right)$, room temperature $\left(25^{\circ} \mathrm{C}\right)$, and hot temperatures $\left(40^{\circ} \mathrm{C}\right)$ for $5 \mathrm{~h}$. Different letters represent significant differences within each temperature $P<0.01$.

of water, while $M$. beecheii and $S$. hellwegeri consumed $0.81 \pm 0.47$ and $0.20 \pm 0.18 \mathrm{ml}$, respectively. In $M$. colimana, a significant correlation ( $r$ $=0.626$ ) occurred between thoracic temperature and water consumption $\quad(F=14.90, \mathrm{DF}=23, P<$ $0.01)$. In the other species, the correlation between thoracic temperature and water consumption was very low and not significant: $S$. hellwegeri, $r=0.271(F=1.83, \mathrm{DF}=23, P>0.01)$, and $M$. beecheii, $r=0.349(F=3.19, \mathrm{DF}=23, P<$ $0.01)$. As for the number of fanning bees (fanning only occurred in M. colimana), an average of $55.72 \pm 11.88$ was recorded, which means that more than half of the group was involved in that behavior. A significant correlation $(r=0.794)$ occurred between fanning bees and water consumption $(F=39.28, \mathrm{DF}=23, P<$ $0.01)$. Under high temperature, workers of $M$. colimana were observed regurgitating drops of water (no syrup was consumed at this temperature) on the floor of the box (between 2 and 5 droplets). In groups of bees that were exposed to

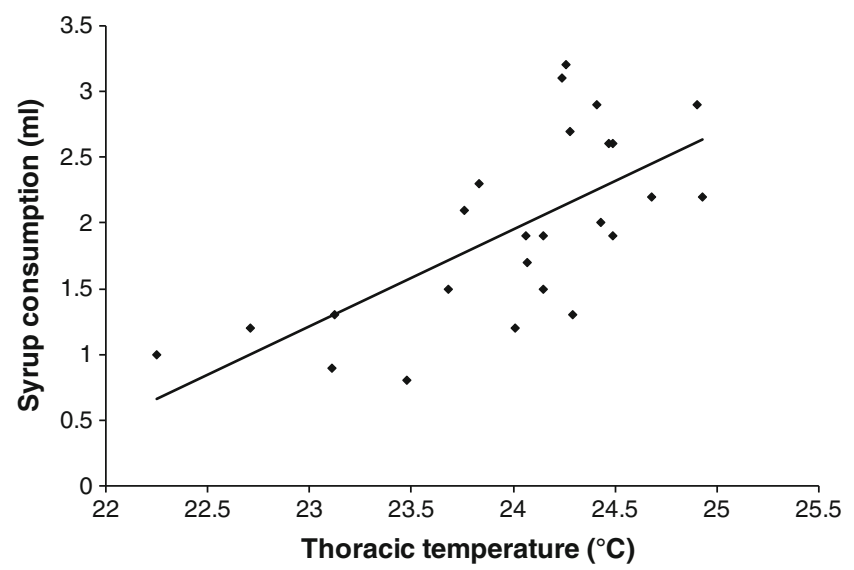

Figure 3. Correlation between bee thoracic temperature and syrup consumption in groups of M. colimana, subjected to $7^{\circ} \mathrm{C}$ for a period of $5 \mathrm{~h}$. 
low temperature for $24 \mathrm{~h}$, the thoracic temperature of the immobile bees was highest in $M$. colimana, and there were significant statistical differences between the three species $(F=14.51$; $\mathrm{DF}=2,12 ; P<0.01)$, and a similar result occurred with the thoracic temperature of bees in motion $(F=392.35 ; \quad \mathrm{DF}=2,12 ; \quad P<0.01)$ (Table I). As for the number of dead bees, $M$. colimana workers showed the lowest mortality under these conditions $(F=39.54 ; \quad \mathrm{DF}=2,12 ; P$ $<0.01$ ), a similar result was obtained for the number of bees which had increased movement $(F=68.96 ; \mathrm{DF}=2,12 ; P<0.01)$ and the time needed for the bees to recover from cold-induced lethargy $(F=36.06 ; \mathrm{DF}=2,12 ; P<0.01), M$. colimana recovered more quickly compared with the other two species. (Table I).

\subsection{Temperature tolerance of adults and pupae}

The mortality rate of adults and pupae for the three species was greater at low temperatures than at high temperatures. In the case of adults, workers of $M$. colimana better tolerated low temperatures compared with the other two species. In contrast, adults of the three species were more tolerant to high temperatures with a minimum mortality at temperatures between $25^{\circ} \mathrm{C}$ and $40^{\circ} \mathrm{C}$ (Figure 4).

The results also showed that $M$. colimana adults tolerated lower mean lethal (LT50) and total lethal temperature (LT100) than other species. In low temperatures, the calculated
LT50 for $M$. colimana adults was $1.7^{\circ} \mathrm{C}$, while for $M$. beecheii and $S$. hellwegeri, it was $3.5^{\circ} \mathrm{C}$ and $5.0^{\circ} \mathrm{C}$, respectively. Similarly, the LT100 for M. colimana adults was $-5^{\circ} \mathrm{C}$, for $M$. beecheii $-2^{\circ} \mathrm{C}$, and all $S$. hellwegeri workers died at $2^{\circ} \mathrm{C}$. Under extreme heat, adult mortality in all species did not reach LT50 or LT100 for the tested temperatures. For all temperatures tested, the point of lowest pupal mortality was found at $25^{\circ} \mathrm{C}$. Below this temperature, mortality increased strongly. In pupae, M. colimana was more resistant to cold than the other two species, all pupae of $M$. beecheii and $S$. hellwegeri died at $5{ }^{\circ} \mathrm{C}$, while $50 \%$ of $M$. colimana pupae survived; however, $100 \%$ of pupae mortality was observed at $2^{\circ} \mathrm{C}$. Comparisons of pupal mortality at high temperatures between the three species showed the lowest in $M$. colimana, followed by $S$. hellwegeri and the highest in $M$. beecheii (Figure 5).

$M$. colimana pupae had a significantly higher LT50 than the other two species $\left(39.1^{\circ} \mathrm{C}\right.$ vs $34^{\circ} \mathrm{C}$ for $M$. beecheii, and $33^{\circ} \mathrm{C}$ for $S$. hellwegeri). As in results in 3.1, all three species used water at different high temperatures and only workers of $M$. colimana consumed syrup at low temperatures. In general, there was a significant positive correlation between high temperatures and water consumption for the three bee species; for $M$. colimana $r=0.89(F=35.85, \mathrm{DF}=9, P<0.01)$, for $M$. beecheii $r=0.93(F=58.52, \mathrm{DF}=9, P<$ $0.01)$, and for $S$. hellwegeri $r=0.80(F=16.19$, $\mathrm{DF}=9, P<0.01)$. For all three species, there

Table I. Means $( \pm \mathrm{SD})$ of thoracic temperature of immobile bees, moving bees, number of bees moving, and time spent recovering for the three species after $24 \mathrm{~h}$ at low temperatures $\left(7^{\circ} \mathrm{C}\right)$.

\begin{tabular}{lllllll}
\hline Species & $\begin{array}{l}\text { Thoracic } \\
\text { temperature of } \\
\text { immobile bees } \\
\left({ }^{\circ} \mathrm{C}\right)\end{array}$ & $\begin{array}{l}\text { Thoracic } \\
\text { temperature of } \\
\text { moving bees } \\
\left({ }^{\circ} \mathrm{C}\right)\end{array}$ & $\begin{array}{l}\text { Time spent } \\
\text { recovering } \\
(\mathrm{min}) .\end{array}$ & $\begin{array}{l}\text { Number of } \\
\text { bees with } \\
\text { movement }\end{array}$ & $\begin{array}{l}\text { Number of } \\
\text { dead bees }\end{array}$ & \% mortality \\
\hline M. colimana & $19.4 \pm 0.43 \mathrm{a}$ & $23.3 \pm 0.12 \mathrm{a}$ & $8.4 \pm 1.14 \mathrm{a}$ & $66.4 \pm 5.94 \mathrm{a}$ & $33.6 \pm 5.9 \mathrm{a}$ & 33.6 \\
M. beecheii & $16.7 \pm 1.05 \mathrm{~b}$ & $20.8 \pm 0.17 \mathrm{~b}$ & $28.0 \pm 5.14 \mathrm{~b}$ & $36.8 \pm 4.32 \mathrm{~b}$ & $64.2 \pm 5.2 \mathrm{~b}$ & 64.2 \\
S. hellwegeri & $18.1 \pm 0.76 \mathrm{c}$ & $21.6 \pm 0.14 \mathrm{c}$ & $20.2 \pm 3.56 \mathrm{c}$ & $32.0 \pm 4.63 \mathrm{~b}$ & $62.0 \pm 6.8 \mathrm{~b}$ & 62.0 \\
\hline
\end{tabular}

Different letters imply significant differences $P<0.01$ 


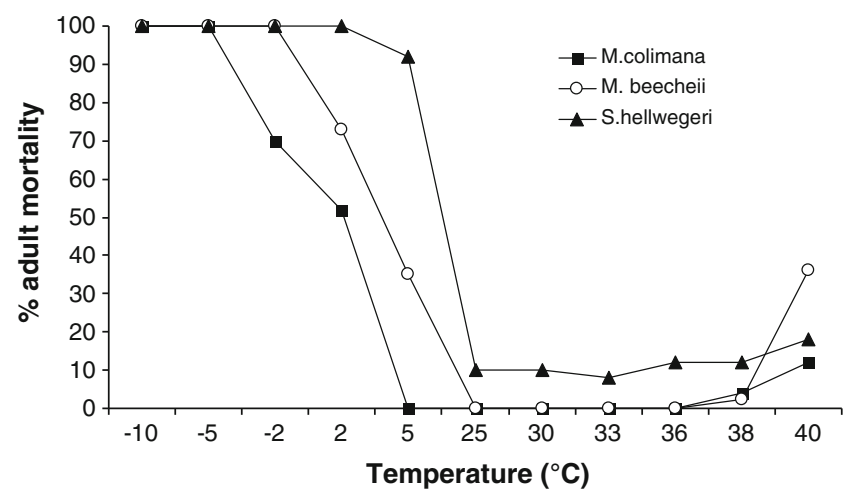

Figure 4. Mortality percentage of adults under different temperatures for a period of $24 \mathrm{~h}$ in $M$. colimana, $M$. beecheii, and $S$. hellwegeri.

was a negative correlation between the experimental temperatures and the percentage of adult and pupal mortality (Table II), corroborating that both adults and pupae are prone to die as temperatures decline.

\section{DISCUSSION}

The results showed that both, the adults and pupae of highland $M$. colimana, better tolerated extreme temperatures compared to $M$. beecheii and $S$. hellwegeri from tropical lowlands. Remarkably, the behavior of water evaporation, never before reported in stingless bees (Jones and Oldroyd 2007), was observed in groups of $M$. colimana workers. Unlike their lowland counterparts, $M$. colimana workers increased sugar syrup consumption and their thoracic temperature in response to a cold environment and, in response to high temperatures, they engaged in water evaporation by means of regurgitation and fanning, which indicates that this species may have developed active mechanisms of temperature control of the nest. However, it will be necessary to conduct studies on whole colonies to determine the relative use of passive and active mechanisms of temperature control in this species under natural and experimental conditions.

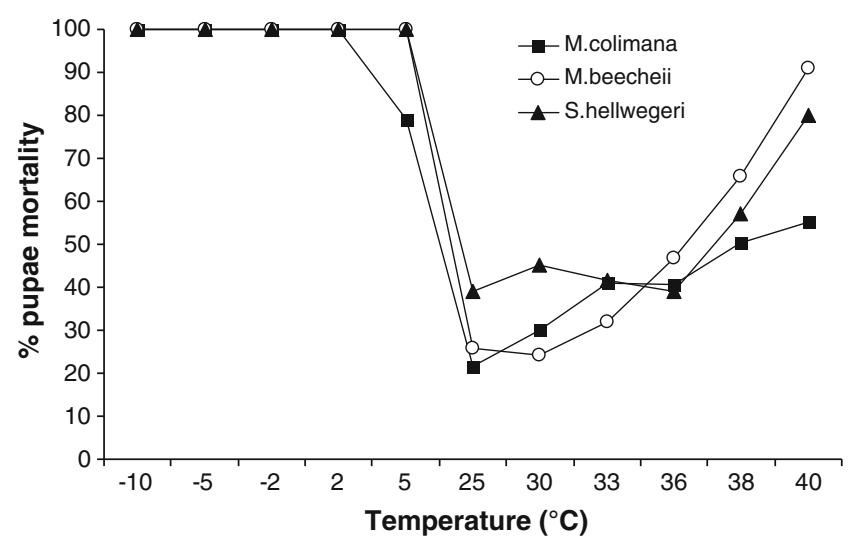

Figure 5. Pupal mortality percentage under different temperatures for a period of $24 \mathrm{~h}$ in $M$. colimana, $M$. beecheii, and S. hellwegeri. 
Table II. Correlations between the experimental temperatures and the mortality percentage of adults and pupae of $M$. colimana, $M$. beecheii, and $S$. hellwegeri for a period of $24 \mathrm{~h}$.

\begin{tabular}{lll}
\hline Species & Adults & Pupae \\
\hline M. colimana & $r=-0.84$ & $r=-0.87$ \\
& $F=21.85, \mathrm{DF}=9, P<0.01$ & $F=28.47, \mathrm{DF}=9, P<0.01$ \\
M. beecheii & $r=-0.88$ & $r=-0.69$ \\
& $F=33.06, \mathrm{DF}=9, P<0.01$ & $F=8.42, \mathrm{DF}=9, P<0.01$ \\
S. hellwegeri & $r=-0.95$ & $r=-0.82$ \\
& $F=97.58 \mathrm{DF}=9, P<0.01$ & $F=18.86, \mathrm{DF}=9, P<0.01$ \\
\hline
\end{tabular}

Under cold temperatures, the individual increase in thoracic temperature was associated with a higher consumption of sugar syrup, which may indicate that $M$. colimana workers may develop active heating of their nests under low environmental temperatures. In fact, heating up the nest under cold ambient temperatures has been reported in stingless bees $S$. postica and Trigona denoiti (Fletcher and Crewe 1981; Engels et al. 1995). Heat generation at the individual basis is considered one of the first steps towards an active system of homeostatic control (Heinrich 1993; Jones et al. 2005; Jones and Oldroyd 2007). Heat generation is also associated with higher sugar intake to fuel the corresponding increase in metabolic heat. Both traits imply that highland $M$. colimana may develop active heat production supported by sugar consumption. However, it is important to assess if the increase of metabolic heat is performed in whole colonies of highland stingless bees and if it can be sustained over long periods of time, as the experiments, where this behavior was observed, only lasted $5 \mathrm{~h}$. Worker heat production is known for other species with temperature control mechanisms such as bumblebees (Bombus spp.) and Apis mellifera, which depend on stored resources to generate metabolic heat (Seeley and Heinrich 1981; Velthuis 2002; Schmolz and Lamprecht 2004; Gurel et al. 2008). However, such species are capable of maintaining nest temperatures over long periods of time, and in the case of $A$. mellifera, this enables them to survive winter periods (Seeley 1995; Tautz 2008) which is not the case in any species of stingless bee. It is also important to consider that body size may have an influence in temperature control as bees with larger body mass could have a potential to produce heat more efficiently (Jones and Oldroyd 2007; Gurel et al. 2008); in this respect, it is interesting that $M$. colimana shows larger body weight $(0.067 \mathrm{~g})$ compared with the other two species, M. beecheii $(0.057 \mathrm{~g})$ and $S$. hellwegeri (0.013), which may also be an adaptation for heat production in $M$. colimana.

In the experiments under high temperatures, M. colimana workers consumed and regurgitated drops of water while fanning their wings; this was not observed neither in $M$. beecheii or $S$. hellwegeri. In natural conditions, there is no evidence that $M$. colimana collects water to cool its colony when ambient temperature increases (unpublished data, Octavio Macías). A positive relationship between increased water consumption and wing ventilation may indicate that these bees are capable of regulating the nest temperature through water evaporation. Wing fanning has been reported in other species of stingless bees (Roubik and Peralta 1983; Moritz and Crewe 1998; Engels et al. 1995), and it is assumed that helps in regulating nest temperature. However, the behavior of regurgitating drops of water and fanning wings in $M$. colimana was similar to that observed in honeybees for cooling down their nest when environmental temperatures increase (Dyer and Seeley 1991; Seeley 1995; Tautz 2008). These behav- 
iors (ventilation, water consumption, regurgitating, and evaporation) are associated with heat regulation and are considered active control mechanisms (Seeley and Heinrich 1981; Jones and Oldroyd 2007). Nevertheless, it will also be necessary to determine the relative importance of these mechanisms in nest thermoregulation of whole colonies of highland stingless bees.

In contrast to other eusocial species like $A$. mellifera, stingless bees may have an exothermic control to maintain body temperature by reducing movements (no energy use) and to survive at low temperature conditions, such a form of exothermic temperature control may allow them to survive outside the colony (Engels et al. 1995). It is known that mature stingless bee drones leave their colony, surviving outdoors for several days (Engels 1988). While cold-induced lethargy was observed in all stingless bee species in our study after $24 \mathrm{~h}$ at low temperatures, the recovery of body movement was faster and the thoracic temperature increased more in M. colimana workers, which also experienced the lower mortality rate suggesting that they have some adaptive mechanism to survive under adverse cold conditions (Engels 1988; Engels et al. 1995). Lethal temperatures were broader for $M$. colimana, which may be further evidence that the workers and pupae of this species were more resistant to extreme temperatures in comparison with $M$. beecheii and S. hellwegeri. In contrast with other species reported to be tolerant to variations in temperature, such as T. angustula and S. postica, the TL50 and TL100 were wider for $M$. colimana that tolerated $3^{\circ} \mathrm{C}$ to $5^{\circ} \mathrm{C}$ below the lethal temperatures recorded for those species (Proni and Hebling 1994; Dias and Aparecido 2004). Thus, highland M. colimana workers seem to have a wide range of tolerance to different temperatures compared to various species that have been studied mainly from lowland tropics (Proni and Hebling 1994; Dias and Aparecido 2004). Such traits are marked differences for the first time recorded in stingless bees and may help to improve survival and adaptation to low temperatures in species living in tropical highlands.

There are various species of stingless bees living in high altitude tropical areas, but they have not been studied thoroughly. The response to extreme temperatures that is reported in this study for $M$. colimana may be present in other species in similar environments. It has been recognized that animal species from the highlands are more likely to deal with heat and cold more effectively than those in relatively more climatically stable tropical lowlands (Ghalambor et al. 2006). The contrasting temperature tolerance of $M$. colimana compared with $M$. beecheii and $S$. hellwegeri could be explained by adaptation to temperature changes in the highlands that can be more extreme on a daily basis than across seasons (Janzen 1967). On the other hand, in tropical lowlands, exposure of stingless bee colonies to extreme temperatures is unlikely and the development of active mechanisms to maintain temperature homeostasis may not be necessary. Thus, stingless bee species in the lowland tropics may depend more on passive mechanisms for temperature regulation of their colonies (nesting sites and nest structures). Accordingly, M. colimana may also have developed a repertoire of behaviors that may enable the colonies to act more like an endothermic organism compared with $M$. beecheii and $S$. hellwegeri that could be regarded as ectothermic ones. The results of the present work may also be used as indication of the relative susceptibility of lowland species of stingless bees to extreme changes in environmental temperature, a fact that may have implications in stingless bee conservation. Recent analyses of worldwide data bases of temperature tolerance in ectothermic organisms showed that tropical species have the greatest risks of extinction from rapid climate change, as a result of their low tolerance to warming and reduced dispersal (Deutsch et al. 2008), both features present in lowland stingless bees. More studies are needed to evaluate the responses of stingless bee species inhabiting highland tropical areas to extreme temperature conditions in order to better understand the 
acclimation and behavioral plasticity of their colonies.

\section{ACKNOWLEDGMENTS}

The authors would like to thank people who have contributed to this work, especially to Angelica Farias S, Jalil Fallad and Judith Hueso. To SEPConacyt project 103341 "Conservacion de las abejas sin aguijon de Mexico (Hymenoptera: Meliponini): Identificacion de especies cripticas e indicadores de diversidad genetica" and Conacyt-Promep for the financial support granted to J. Octavio Macías-Macías to achieve a doctoral degree at the Universidad Autonoma de Yucatan, and to Bernardo Soto and Gustavo Alcazar and to the Centro Universitario del Sur (CUSUR) of the Universidad de Guadalajara for providing facilities in which the experiments were conducted.

Comparaison de la tolérance à la température chez des espèces d'abeilles sans aiguillon des hautes et basses terres tropicales du Mexique; implication pour leur conservation (Hymenoptera: Apidae: Meliponini)

Melipona / Scaptotrigona / Apidae / tolérance à la température / comportement / forêt tempérée / Mexique

\section{Temperaturtoleranz von stachellosen Bienen aus den tropischen Hochländern und den Tieflandgebieten in Mexiko im Vergleich, und ihre Konsequenzen für den Artenschutz (Hymenoptera: Apidae: Meliponini)}

\section{Melipona / Scaptotrigona / Apidae / Temperaturto- leranz / Verhalten / Wald der gemäßigten Zonen / Mexiko}

\section{REFERENCES}

Ayala, R. (1999) Revisión de las abejas sin Aguijón de México, (Hymenoptera: Apidae: Meliponini). Fol Entom Mex 106, 1-123

Cauich, O., Quezada-Euan, J.J.G., Macias-Macias, J.O., Reyes-Oregel, V., Medina-Peralta, S., Parra-Tabla, V. (2004) Behaviour and pollination efficiency of Nannotrigona perilampoides (Hymenoptera: Meliponini) on greenhouse tomatoes (Lycopersicon esculentum) in subtropical Mexico. J Econ Entomol 97, 475-481
CONAGUA (2007a) Archivos Observatorio Metereologico Regional de Merida. Comision Nacional del Agua. Yucatan, Mexico.

CONAGUA. (2007b) Observatorio Metereologico Regional, archivos Zona Sur de Jalisco, Comisión Nacional del Agua, Cd. Guzman, Mpio de Zapotlán el Grande. Jalisco. Mexico.

Deutsch, A.C., Tewksbury, J.J., Huey, B.R., Sheldon, S. K., Ghalambor, K.C., Haak, C.D., Martin, R.P. (2008) Impacts of climate warming on terrestrial ectotherms across latitude. Proc Natl Acad Sci 105, 6668-6672

Dias, M.O.J., Aparecido, P.E. (2004) Capacidade de resistencia a altas e baixas temperaturas em operarias de Scaptotrigona postica (Latreille) (Hymenoptera, Apidae) durante os períodos de verãoe inverno. Rev Bras Zool 21, 893-896

Dyer, F.C., Seeley, T.D. (1991) Nesting behavior and the evolution of worker tempo in four honey bee species. Ecology 72, 156-170

Engels, W. (1988) Fortpflanzungsstrategien bei Bienen. Reproductive strategies in bees. Verh Dtsch Zool Ges 81, 155-167

Engels, W., Rosenkranz, P., Engels, E. (1995) Thermoregulation in the nests of the neotroprical stingless bee Scaptotrigona postica and a hypothesis on the evolution of temperature homeostasis in highly eusocial bees. Stud Neotrop Fauna Environ 30, 193-205

Fletcher, D.J.C., Crewe, R.M. (1981) Nest structure and thermoregulation in the stingless bee Trigona (Plebeina) denoti Vachal (Hymenoptera: Apidae). J Entomol Soc South Afr 44, 183-196

Frazier, M.R., Huey, R.B., Berrigan, D. (2006) Thermodynamics constrains the evolution of insect population growth rates: "Warmer is better". Am Nat 168, 512-520

Ghalambor, C.K., Huey, R.B., Martin, P.R., Tewksbury, J. J., Wang, G. (2006) Are mountain passes higher in the tropics? Janzen's hypothesis revisited. Integr Comp Biol 46, 5-17

Gurel, F., Gosterit, A., Eren, O. (2008) Life-cycle and foraging patterns of native Bombus terrestris (L.) (Hymenoptera: Apidae) in the Mediterranean region. Insect Soc 55, 123-128

Heinrich, B. (1993) The hood blooded Insects: strategies and mechanisms of thermoregulation. Springer Verlag, Germany

Huey, R.B., Stevenson, R.D. (1979) Integrating thermal physiology and ecology of ectotherms: Discussion of approaches. Am Zool 19, 357-366

Janzen, D.H. (1967) Why mountain passes are higher in the tropics. Am Nat 101, 233-249

Jones, C.J., Oldroyd, P.B. (2007) Nests thermoregulation in social insects. In: Simpson, S.J. (ed.) Advances in Insect Physiology, pp. 154-185. Elsevier, Oxford 
Jones, C.J., Helliwell, P., Beekman, M., Maleszka, R., Oldroyd, P.B. (2005) The effects of rearing temperature on developmental stability and learning and memory in the honeybee Apis mellifera. J Comp Physiol 191, 1121-1129

Mardan, M., Kevan, G.P. (2002) Critical temperatures for survival of brood and adult workers of the giant honeybee Apis dorsata (Hymenoptera: Apidae). Apidologie 33, 295-301

Mc Mullan, J.B., Brown, M.J.F. (2005) Brood pupation temperature affects the susceptibility of honeybees (Apis mellifera) to infestation by tracheal mites (Acarapis woodi). Apidologie 36, 97-105

Moritz, R.F.A., Crewe, R.M. (1998) Air ventilation in nests of two African stingless bees Trigona denoiti and Trigona gribodoi. Experientia 44, 1024-1027

Nogueira-Neto, P. (1997) Vida e criação de abelhas indígenas sem ferrão. São Paulo, Brasil

Ortiz-Mora, A., Van Veen, J.W., Corrales-Moreira, G., Sommeijer, M.J. (1995) Influence of altitude on the distribution of Stingless bees (Hymenoptera: Apidae: Meliponinae). Apiacta 30, 101-105

Proni, E.A., Hebling, M.J.A. (1994) Tolerance to temperature variation in workers of Tetragonisca angustula fiebrigi Schwars, 1938 and Tetragonisca angustula angustula Latreille, 1807 (Hymenoptera: Apidae). Rev Bras Biol 54, 85-90

Roubik, D.W. (1983) Nest and colony characteristics of Stinglees bees from Panama (Hymenoptera: Apidae). J Kans Entomol Soc 55, 789-800

Roubik, D.W. (2006) Stingless bee nesting biology. Apidologie 37, 1-20

Roubik, D.W., Peralta, A.F.J. (1983) Thermodynamics in nests of two Melipona species in Brazil. Act Amaz 13, 453-466

Sakagami, S.F. (1982) Stingless bees. In: Herman, H.R. (ed.) Social Insects, pp. 36-423. Academic, London
Schmolz, E., Lamprecht, I. (2004) Thermal investigations on social insects. In: Lorinczy, D. (ed.) The Nature of Biological Systems as Revealed by Thermal Methods, pp. 251-283. Kluwer Academic, The Netherlands

Seeley, T.D. (1995) The wisdom of the hive. Harvard University Press, Cambridge

Seeley, T.D., Heinrich, B. (1981) Regulation of temperature in the nest of social insects. In: Heinrich, B. (ed.) Insect Thermoregulation, pp. 159-234. Wiley, New York

SPSS. (2006) Statistical Package for the Social Sciences, SPSS for windows. SPSS, Inc., Chicago

Statistical Graphics Corp. (1999) Statgraphics Plus for Windows 4.1 Copyright. Statistical Graphics Corp., Princeton

Tautz, J. (2008) The buzz about bees: Biology of a superorganism. Springer-Verlag, Berlin

Tautz, J., Maier, S., Groh, C., Rossler, W., Brockmann, A. (2003) Behavioral performance in adults honeybees is influenced by the temperature experienced during their pupal development. Proc Natl Acad Sci 100, 7343-7347

Velthuis, H.H.W. (2002) The historical background of the domestication of the bumble-bee Bombus terrestris and its introduction in agriculture. In: Kevan, P., Imperatriz-Fonseca, V.L. (eds.) Pollinating Bees: The Conservation Link Between Agriculture and Nature, pp. 177-184. Ministry of Environment, Brasilia

Wille, A. (1983) Biology of stingless bees. Annu Rev Entomol 28, 42-46

Zar, J. (1999) Biostatistic analisis. Prentice Hall, New York

Zucchi, R., Sakagami, S.F. (1972) Capacidade termoreguladora em Trigona spinipes e em algumas uotras espécies de abelhas Sem Ferrão (Hymenoptera: Apidae: Meliponinae). In: Hebling, S.P., Lello, E., de Takahashi, C.S. (eds.) Homenagem a Warwick Estevam Kerr, Brasil, pp. 301-310 